ROCZNIK ADMINISTRACJI PUBLICZNEJ 2021 (7)

ARTYKUtY / ARTICLES

Administracyjne prawo materialne Administrative Material Law

Anna Mrrczek ${ }^{1}$

\title{
Prawa pasażera lotniczego w Europie w dobie COVID-19
}

\section{Wstęp}

Epidemia COVID-19 bez wątpienia zmieniła otaczającą nas rzeczywistość. Ograniczenia wprowadzone w związku z pandemią dotknęly wszystkich dziedzin gospodarki, lecz szczególnie uderzyły w sektor transportowy oraz turystyczny. W okresie pandemii pomimo spadku liczby operacji lotniczych wzrosła liczba sytuacji spornych. Nietypowa sytuacja obnażyła mankamenty obecnych regulacji oraz konieczność dalszej harmonizacji przepisów prawa na poziomie Unii Europejskiej. Epidemia ujawniła niedostateczne regulacje w zakresie pośredników lotniczych. Niniejsze opracowanie ma charakter przeglądowy. W procesie powstawania artykułu dokonano przeglądu istniejącej literatury przedmiotu, w tym publikacji instytucji Unii Europejskiej. Artykuł oparty jest także o wieloletnie doświadczenie autorki w prowadzeniu polubownych postępowań pasażerskich. Opracowanie skupia się na przedstawieniu ram prawnych, regulujących prawa pasażera lotniczego w Europie, oraz problemów napotykanych przez konsumentów, zaobserwowanych w praktyce Europejskiego Centrum Konsumenckiego $\mathrm{w}$ Polsce, $\mathrm{w}$ toku prowadzonych postępowań polubownych. Celem pracy jest analiza sytuacji na rynku lotniczym w okresie pandemii z punktu widzenia interesów pasażera oraz weryfikacja tezy o adekwatności istniejących regulacji prawnych.

\section{Prawa pasażera w Polsce i Europie}

\subsection{Konwencja Montrealska}

Jednym z podstawowych aktów prawnych regulujących prawa pasażera w ujęciu globalnym, jest Konwencja o ujednoliceniu niektórych zasad

1 Mgr Anna Myrczek, prawnik, doradca, Europejskie Centrum Konsumenckie Polska. 
dotyczących międzynarodowego przewozu lotniczego, podpisana w Montrealu 28 maja $1999 \mathrm{r}$.

Konwencja Montrealska uzupełniła wcześniejszą Konwencję Warszawską z 1929 r. ${ }^{2}$, która, wraz z późniejszymi, dodatkowymi protokołami stanowi tzw. system warszawski, kompleksowo regulujący kwestie międzynarodowego przewozu lotniczego. Ponieważ konwencja nie zobowiązuje państw-sygnatariuszy do wypowiedzenia wcześniejszych umów - w chwili obecnej międzynarodowy przewóz lotniczy regulują równocześnie Konwencja Warszawska z 1929 r., Konwencja Warszawska w postaci zmodyfikowanej przez Protokół Haski z 1955 r. oraz Konwencja Montrealska z 1999 r. $^{3}$. Według danych Organizacji Międzynarodowego Lotnictwa Cywilnego - ICAO ${ }^{4}$, obecnie stronami Konwencji Warszawskiej pozostają 152 państwa, podczas gdy Konwencji Montrealskiej - 137 podmiotów (w tym 136 państw oraz Unia Europejska).

Konwencja znajduje zastosowanie do międzynarodowego przewozu osób, bagażu oraz ładunku dokonywanego drogą powietrzną między terytoriami należącymi do państw-sygnatariuszy. Konwencja Montrealska nie będzie więc stosowana do przewozów wewnątrzkrajowych, przewozów rozpoczynających się oraz kończących się w państwach niebędących jej stronami oraz przewozów między terytoriami państw, z których jedynie jedno przystąpiło do Konwencji ${ }^{5}$.

Warto zaznaczyć, że chociaż tekst Konwencji wyraźnie ogranicza zakres zastosowania wyłącznie do lotów międzynarodowych na terytorium Unii Europejskiej, na mocy Rozporządzenia 889/2002, przepisy Konwencji stosuje się także w przypadku lotów wewnątrzwspólnotowych oraz lotów wewnętrznych każdego państwa członkowskiego ${ }^{6}$.

Konwencja Montrealska nie określa praw pasażera w przypadku niewykonania przewozu. W tym zakresie istnieją jedynie ogólne postanowienia dotyczące odpowiedzialności przewoźnika za szkody ${ }^{7}$. Na gruncie prawa Unii Europejskiej, lukę tę uzupełnia Rozporządzenie 261/2004, jednak zakres terytorialny jego obowiązywania jest ograniczony.

2 Konwencja o ujednostajnieniu niektórych prawideł dotyczących międzynarodowego przewozu lotniczego podpisana w Warszawie 12 października 1929 r. Dz. U. 1933 nr 8 poz. 49.

3 M. Polkowska, I. Szymajda, Konwencja Montrealska. Komentarz. Odpowiedzialność cywilna przewoźnika lotniczego, Warszawa 2004, s. 15-17.

4 www.icao.int (dostęp: 11.07.2021).

5 A. Kunert-Diallo, Kolizje praw w międzynarodowym transporcie lotniczym, Warszawa 2011.

6 Rozporządzenie nr 889/2002 Parlamentu Europejskiego i Rady z dnia 13 maja 2002 r. zmieniającego Rozporządzenie Rady (WE) nr 2027/97 w sprawie odpowiedzialności przewoźnika lotniczego z tytułu wypadków lotniczych, (Dz. U. L 140, 30.5.2002, p. 2).

7 M. Polkowska, I. Szymajda, op. cit., s. 21. 
Z punktu widzenia praw pasażera, znaczenie mają postanowienia Konwencji, dotyczące odpowiedzialności przewoźnika za śmierć oraz uszkodzenie ciała, a szczególnie odpowiedzialności przewoźnika za uszkodzenie lub utratę bagażu.

\subsubsection{Uszczerbek na zdrowiu lub śmierć pasażera}

Zasady odpowiedzialności przewoźnika za śmierć, uszkodzenie ciała lub zdrowia pasażerów, określa art. 17 ust. 1 Konwencji. Przewoźnik ponosi odpowiedzialność za szkodę wynikłą w przypadku śmierci lub uszkodzenia ciała pasażera, jedynie pod warunkiem, że wypadek, który spowodował śmierć lub uszkodzenie ciała miał miejsce na pokładzie statku powietrznego lub w trakcie jakiejkolwiek czynności związanej z wsiadaniem lub wysiadaniem.

Pewien problem interpretacyjny stanowi tłumaczenie francuskiego pojęcia lésion corporelle, a także angielskiego pojęcia bodily injury oraz ustalenie, czy pojęcie to obejmować może także uraz psychiczny ${ }^{8}$. W tłumaczeniu polskim zdecydowano się na wykorzystanie pojęcia "uszkodzenia ciała", choć nie wydaje się, by oddawało ono w pełni istotę francuskiego pojęcia.

Choć pojęcie uszkodzenia ciała było przedmiotem dyskusji państw-sygnatariuszy, nie udało się ustalić jednolitej definicji pojęcia w rozumieniu Konwencji. W związku z powyższym, sądy właściwe do rozstrzygnięcia sporu, zmuszone są odnosić się do definicji krajowych ${ }^{10}$. $\mathrm{Z}$ powodu różnic interpretacyjnych, niektóre państwa proponowały zmianę pojęcia bodily injury na bardziej ogólne injury albo personal injury lub też wyodrębnienie osobnej kategorii mental injury, jako podstawy roszczeń pasażera. W toku rozmów uznano jednak, że nie ma konieczności zmiany użytych w Konwencji pojęć, ponieważ, mimo że zakres pojęcia znacząco różnił się w systemach prawnych poszczególnych krajów, nie kwestionowano samej możliwości dochodzenia zadośćuczynienia także za krzywdy moralne. Punkt sporny stanowił jedynie zakres kompensacji takich szkód ${ }^{11}$. Jak podkreśla Anna Konert, istotny z punktu widzenia oceny roszczeń powinien być związek między zaistniałą krzywdą moralną, a zdrowiem pasażera ${ }^{12}$.

Kluczowe dla oceny roszczeń pasażera jest pojęcie wypadku, który spowodował śmierć lub uszkodzenie ciała. Konwencja nie definiuje czym jest „wypadek” oraz, co odróżnia go od „zdarzenia” dotyczącego odpowiedzialności za bagaż. A. Konert zauważa, że pojęcie wypadku jest odmiennie rozumiane oraz interpretowane $\mathrm{w}$ ramach różnych systemów prawnych ${ }^{13}$,

8 Ibidem, s. $48-49$.

9 Dokładniej: śmierć, uszkodzenie ciała lub rozstrój zdrowia - za A. Konert, Odpowiedzialność cywilna..., s. 106.

10 Ibidem, s. 48.

11 A. Konert, op. cit., s. 104-106.

12 Ibidem.

13 Ibidem, s. 109. 
większość badaczy zgadza się jednak, że wypadek obejmuje zdarzenie niezwykłe oraz nieoczekiwane.

Wątpliwości dotyczą także "jakiejkolwiek czynności związanej z wsiadaniem lub wysiadaniem". W praktyce orzeczniczej wypracowano test, pozwalający na określenie, czy przewoźnik będzie odpowiedzialny za wypadek. Wyróżniono trzy podstawowe czynniki:

1) Miejsce wypadku;

2) Działanie/zachowanie pasażera w momencie wypadku;

3) Określenie pod czyją opieką znajdował się pasażer ${ }^{14}$.

$\mathrm{Z}$ uwagi na odmienne interpretacje, trudno wskazać, które wypadki objęte będą zakresem konwencji. Jak zauważają M. Polkowska oraz I. Szymajda, w niektórych państwach uznaje się, że pasażer znajduje się pod opieką przewoźnika po przejściu procedury check-in, $\mathrm{w}$ innych zaś, że moment objęcia opieką następuje po zaproszeniu pasażerów na pokład ${ }^{15}$. A. Konert sugeruje, że pewnym kompromisem mogłoby zostać wprowadzenie odpowiedzialności od momentu wejścia do tzw. odizolowanej strefy pasażerów, tj. strefy dostępnej jedynie dla pasażerów danego lotu ${ }^{16}$. Wydaje się jednak, że $\mathrm{z}$ uwagi na różnice $\mathrm{w}$ organizacji portów lotniczych, zastosowanie powyższej konstrukcji może okazać się niewystarczające. Każdy przypadek wymaga indywidualnej oceny, w oparciu o okoliczności sprawy.

Ma to szczególne znaczenie w związku z art. 20 Konwencji, przewidującym zwolnienie przewoźnika od odpowiedzialności, jeśli udowodnił on, że szkodę spowodowało, lub przyczyniło się do niej niedbalstwo albo inne bezprawne działanie lub zaniechanie poszkodowanego lub osoby, od której wywodzi ona swoje prawa. Przewoźnik zwolniony jest od odpowiedzialności w całości lub w części, w zakresie, w jakim działanie to przyczyniło się do powstania szkody.

Konwencja wprowadza dwustopniowy reżim odpowiedzialności przewoźnika (art. 21 Konwencji). O ile nie zajdą okoliczności wymienione w art. 20, przewoźnik nie może uwolnić się od odpowiedzialności za szkody spowodowane śmiercią lub uszkodzeniem ciała pasażera do wysokości 100000 SDR $^{17}$. Postanowienie to przewiduje obiektywną, niezależną od winy odpowiedzialność przewoźnika, nie wyłączając jednak późniejszego prawa regresu (art. 37 Konwencji), jeśli wykaże on, że winę za zdarzenie ponosi inny podmiot. W przypadku szkód przewyższających 100000 SDR na pasażera, przewoźnik ponosi odpowiedzialność, jeśli szkodę spowodowało niedbalstwo lub inne bezprawne działanie przewoźnika lub osoby działającej w jego imieniu (pracowników i agentów) oraz w przypadku, gdy

14 M. Polkowska, I. Szymajda, Konwencja Montrealska. Komentarz..., op. cit., s. 53.

15 Ibidem.

16 A. Konert, Odpowiedzialność cywilna..., op. cit.,s. 126.

17 Special Drawing Rights - Specjalne Prawa Ciągnienia: Jednostka rozliczeniowa Konwencji Montrealskiej. Od 28 grudnia 2019 r. limit odpowiedzialności przewoźnika został podniesiony do 128821 SDR. 
nie udowodnił, że szkoda została spowodowana wyłącznie niedbalstwem lub innym bezprawnym działaniem lub zaniechaniem strony trzeciej.

Ciekawym rozwiązaniem jest możliwość niezwłocznej wypłaty zaliczek na poczet odszkodowania w przypadku śmierci lub uszkodzenia ciała pasażera (art. 28): wypłacenie zaliczki nie stanowi uznania odpowiedzialności przewoźnika, lecz ma na celu zabezpieczenie doraźnych potrzeb osób poszkodowanych wypadkiem.

W praktyce, $\mathrm{z}$ uwagi na konieczność przeprowadzenia dokładnego postępowania dowodowego, sprawy dotyczące uszkodzenia ciała lub śmierci niezwykle rzadko są prowadzone $\mathrm{w}$ ramach polubownych postępowań konsumenckich.

2.1.2 Opóźnienie

Konwencja Montrealska w art. 19 przewiduje odpowiedzialność przewoźnika za szkodę wynikającą z opóźnienia w przewozie lotniczym osób, bagażu lub ładunku. Przewoźnik może zwolnić się od odpowiedzialności, jeśli wykaże, że przewoźnik, jego pracownicy i agenci podjęli wszelkie rozsądne konieczne środki, aby uniknąć powstania szkody lub że podjęcie takich środków nie było możliwe.

Niestety Konwencja nie zawiera szczegółowej definicji, ani minimalnego czasu trwania opóźnienia. W większości spraw, dotyczących opóźnienia na terytorium Unii Europejskiej, zastosowanie znajdują przepisy rozporządzenia 261/2004. Przepisy te, wraz z wydanymi do nich wytycznymi interpretacyjnymi, dostarczają bardziej szczegółowych informacji w zakresie opóźnienia oraz odpowiedzialności przewoźnika, a także ułatwiają dochodzenie roszczeń pasażerom przez prowadzenie zryczałtowanego odszkodowania.

\subsubsection{Bagaż}

Konwencja Montrealska obejmuje swoimi postanowieniami także lotniczy transport bagażu. W praktyce instytucji konsumenckich, skargi bagażowe stanowią trzecią najbardziej liczną kategorię skarg, tuż po kwestiach związanych z odwołaniem oraz opóźnieniem lotu.

Według art. 17 Konwencji, przewoźnik ponosi odpowiedzialność za szkodę wynikłą w razie zniszczenia, utraty lub uszkodzenia bagażu, zarówno przyjętego, jak i nieprzyjętego. Istotne jest jednak, że w przypadku bagażu przyjętego (rejestrowanego), przewoźnik ponosi odpowiedzialność pod warunkiem, że wydarzenie, które spowodowało zniszczenie, utratę lub uszkodzenie bagażu nastąpiło na pokładzie statku powietrznego albo podczas jakiegokolwiek okresu, w którym przyjęty bagaż znajdował się pod jego opieką. W zakresie bagażu nieprzyjętego (podręcznego), przewoźnik ponosi odpowiedzialność wyłącznie, w sytuacji jeśli szkoda wynikła $\mathrm{z}$ jego błędu lub błędu jego pracowników bądź agentów (art. 17 ust. 2 Konwencji). 
W przypadku lotów łączonych, realizowanych przez kolejnych przewoźników lotniczych, ponoszą oni solidarną odpowiedzialność za przyjęty bagaż (art. 36 ust. 3 Konwencji). Pasażer może więc skierować swoje roszczenia do każdego z przewoźników wykonujących przewóz.

$\mathrm{W}$ razie zagubienia lub zniszczenia bagażu istotne jest niezwłoczne zgłoszenie szkody oraz uzyskanie stosownego dowodu (Property Irregularity Report - PIR). Zgodnie z art. 31 ust. 1 Konwencji, odebranie przez pasażera bagażu bez wniesienia skargi przed opuszczeniem obszaru tranzytowego lotniska, objęte jest domniemaniem faktycznym, że bagaż został dostarczony w dobrym stanie.

W przypadku bagażu Konwencja ograniczyła odpowiedzialność przewoźnika do 1000 SDR na pasażera. Wyjątek stanowi sytuacja, w której pasażer podczas oddawania bagażu złoży specjalną deklarację interesu oraz wniesie stosowną opłatę jeśli ma ona zastosowanie. Limity odszkodowań przewidzianych Konwencją. od momentu jej uchwalenia były dwukrotnie rewidowane: w 2009 r. podniesiono wysokość odszkodowania do 1131 SDR, zaś od 28 grudnia 2019 roku - do 1288 SDR $^{18}$.

Choć niniejsze opracowanie nie zawiera dokładnego opisu postanowień Konwencji w zakresie ładunku, warto wspomnieć, że odpowiedzialność przewoźnika za ładunek ograniczona jest do 17 SDR $/ \mathrm{kg}$ (od 2019 r. 22 SDR). Wiadomość ta jest istotna z punktu widzenia pasażerów, gdyż część linii lotniczych - w momencie, gdy konsument nie jest w stanie wykazać wysokości szkody, pomocniczo opiera się na postanowieniach w zakresie ładunku, obliczając kwotę odszkodowania według wagi bagażu.

Chociaż uzyskany na lotnisku protokół PIR stanowi dowód potwierdzający istnienie szkody, ciężar dowodowy w zakresie wykazania wysokości szkody spoczywa na pasażerze. Najczęściej linie lotnicze wymagają od pasażerów przesłania listy zawartości zagubionego bagażu wraz z dowodami zakupu. W praktyce stwarza to wiele problemów, gdyż zdecydowana większość konsumentów nie przechowuje paragonów za rzeczy codziennego użytku.

Konwencja reguluje także utratę bagażu (art. 17 ust. 4). Za utracony bagaż można uznać taki, który nie dotarł do pasażera w terminie 21 dni od dnia lotu. Po upływie tego terminu pasażer ma możliwość dochodzenia od przewoźnika odszkodowania przewidzianego postanowieniami Konwencji.

W zakresie zgłaszania roszczeń, artykuł 31 ust. 3 Konwencji przewiduje obowiązek zgłoszenia skargi do przewoźnika w formie pisemnej oraz krótki, zawity termin zgłaszania skarg. W przypadku uszkodzenia bagażu rejestrowanego wynosi on $7 \mathrm{dni}$ od momentu odebrania bagażu, w przypadku opóźnienia bagażu skargę należy wnieść najpóźniej w ciągu 21 dni od momentu otrzymania bagażu. Niedotrzymanie ww. terminów na mocy art. 31

18 Źródło: https://www.icao.int/secretariat/legal/Pages/2019_Revised_Limits_of_ Liability_Under_the_Montreal_Convention_1999.aspx (dostęp: 11.07.2021). 
ust. 4 Konwencji, powoduje wyłączenie prawa do powództwa przeciwko przewoźnikowi, z wyjątkiem sytuacji, gdy ze strony przewoźnika miało miejsce nadużycie finansowe.

Z uwagi na długi czas obowiązywania konwencji, strony przewidziały możliwość rewizji ustalonych limitów, z czego dotychczas skorzystano dwukrotnie. Aktualną wysokość limitów odpowiedzialności obrazuje poniższa tabela.

Tabela 1. Wysokość limitów odpowiedzialności przewoźnika według Konwencji Montrealskiej $^{19}$

\begin{tabular}{|l|c|c|c|}
\hline \multicolumn{1}{|c|}{$\begin{array}{c}\text { Artykuł Konwencji } \\
\text { Montrealskiej }\end{array}$} & $\begin{array}{c}\text { Oryginalny } \\
\text { limit SDR } \\
(1999)\end{array}$ & $\begin{array}{c}\text { Limit } \\
\text { obowiązujący } \\
\text { od 30 grudnia } \\
\text { 2009 r. }\end{array}$ & $\begin{array}{c}\text { Limit } \\
\text { obowiązujący } \\
\text { od 28 grudnia } \\
\text { 2019 r. }\end{array}$ \\
\hline $\begin{array}{l}\text { Art. 21 } \\
\text { (śmierć/uszkodzenie ciała) }\end{array}$ & 100000 & 113100 & 128821 \\
\hline Art. 22 ust. 1 (opóźnienie) & 4150 & 4694 & 5346 \\
\hline $\begin{array}{l}\text { Art. 22 ust. 2 } \\
\text { (uszkodzenie/opóźnienie/ } \\
\text { utrata bagażu) }\end{array}$ & 1000 & 1131 & 1288 \\
\hline $\begin{array}{l}\text { Art. 22 ust. 3 } \\
\text { (uszkodzenie/opóźnienie/ } \\
\text { utrata ładunku) }\end{array}$ & $17 / \mathrm{kg}$ & $19 / \mathrm{kg}$ & $22 / \mathrm{kg}$ \\
\hline
\end{tabular}

2.2 Rozporządzenie $261 / 2004$

Jak wspomniano powyżej, w Unii Europejskiej podstawowym aktem prawnym regulującym prawa pasażera jest rozporządzenie nr 261/2004, ustanawiające wspólne zasady odszkodowania i pomocy dla pasażerów w przypadku odmowy przyjęcia na pokład albo odwołania lub dużego opóźnienia lotów, uchylające rozporządzenie (EWG) nr 295/911 (rozporządzenie 261/2004).

Zgodnie $\mathrm{z}$ art. 3 rozporządzenia znajduje ono zastosowanie do wszystkich lotów odbywających się z terytorium Unii Europejskiej oraz do lotów rozpoczynających się poza UE i lądujących na jej terytorium, jeśli są one wykonywane przez przewoźnika wspólnotowego. Oznacza to, że w przypadku lotów wykonywanych przez przewoźnika nie wspólnotowego np. zarejestrowanego w Turcji, lot z Warszawy do Ankary podlegałby przepisom rozporządzenia, jednakże nie znalazłyby one zastosowania w przypadku lotu powrotnego Ankara - Warszawa. W przypadku lotu na tej samej trasie, obsługiwanego przez przewoźnika wspólnotowego rozporządzenie

19 Źródło: https://www.icao.int/secretariat/legal/Pages/2019_Revised_Limits_of_ Liability_Under_the_Montreal_Convention_1999.aspx (dostęp 11.07.2021). 
byłoby stosowane. W tym miejscu warto zaznaczyć, że w związku z opuszczeniem przez Wielką Brytanię Unii Europejskiej - od 1 stycznia $2021 \mathrm{r}$. loty do Wielkiej Brytanii nie mają statusu lotów wewnątrzwspólnotowych. Oznacza to, że w przypadku znacznego opóźnienia lotu z Londynu do Warszawy obsługiwanego przez PLL LOT pasażerowie będą mogli dochodzić roszczeń $\mathrm{w}$ oparciu o przepisy rozporządzenia, lecz $\mathrm{w}$ przypadku tej samej trasy obsługiwanej przez British Airways rozporządzenie nie znajdzie zastosowania.

Rozporządzenie 261/2004 nie znajduje zastosowania do terytoriów wymienionych w załączniku II do Traktatu o funkcjonowaniu Unii Europejskiej (TFUE), lecz jest stosowane do Azorów, Gujany Francuskiej, Gwadelupy, Madery, Majotty, Martyniki, Reunionu, Saint-Martin oraz Wysp Kanaryjskich ${ }^{20}$.

Rozporządzenie reguluje przede wszystkim prawa pasażera $\mathrm{w}$ przypadku odwołania lub opóźnienia lotu, odmowy przyjęcia na pokład oraz umieszczenia w klasie wyższej/niższej a także w zakresie dostępu do informacji oraz praw osób z niepełnosprawnością.

\subsubsection{0dmowa przyjęcia na pokład}

Pierwszą $\mathrm{z}$ okoliczności wymienionych $\mathrm{w}$ rozporządzeniu jest odmowa przyjęcia na pokład (art. 4). Przepis ten wskazuje, że jeśli przewoźnik przewiduje odmowę przyjęcia na pokład, powinien on w pierwszej kolejności wezwać ochotników do rezygnacji na warunkach ustalonych między pasażerem a obsługującym przewoźnikiem lotniczym. Oznacza to, że pasażer ma możliwość wynegocjowania korzyści większych, niż zagwarantowane przepisami rozporządzenia. W razie braku wystarczającej ilości ochotników, przewoźnik może podjąć decyzję o odmowie przyjęcia na pokład wbrew woli pasażera. W większości przypadków, przyczyną odmowy przyjęcia na pokład jest tzw. overbooking lub względy techniczne.

Warto zaznaczyć, że nie każda decyzja o niewpuszczeniu na pokład uprawnia pasażera do otrzymania odszkodowania, opieki oraz podróży alternatywnej. Jeśli pasażer nie zostaje wpuszczony na pokład z powodu braku odpowiednich dokumentów podróżnych, ze względów bezpieczeństwa, czy też ze względów zdrowotnych - sytuacja taka nie będzie objęta zakresem zastosowania rozporządzenia. Wyjątek stanowi przypadek, gdy obsługa naziemna lub pracownicy przewoźnika, niesłusznie odmówią

20 Zawiadomienie Komisji - Wytyczne interpretacyjne dotyczące rozporządzenia WE nr 261/2004 Parlamentu Europejskiego i Rady ustanawiającego wspólne zasady odszkodowania i pomocy dla pasażerów w przypadku odmowy przyjęcia na pokład albo odwołania lub dużego opóźnienia lotów oraz rozporządzenia Rady (WE) nr 2027/97 w sprawie odpowiedzialności przewoźnika lotniczego z tytułu wypadków lotniczych zmienionego rozporządzeniem (WE) nr 889/2002 Parlamentu Europejskiego i Rady, Dz. Urz. UE C 214 z 15.06.2016 poz. 4. 
pasażerowi przyjęcia na pokład w wyniku błędu (np. z powodu braku wizy w przypadku pasażera objętego ruchem bezwizowym ${ }^{21}$.

2.2.2 0dwołanie lotu

Drugim zdarzeniem, objętym zakresem rozporządzenia jest odwołanie lotu. Według definicji wskazanej w art. 2 ust. 1 rozporządzenia: odwołanie to nieodbycie się lotu, który był uprzednio planowany i na który zostało zarezerwowane przynajmniej jedno miejsce. Według wytycznych interpretacyjnych do uznania lotu za odwołany nie jest konieczna wyraźna decyzja przewoźnika - wystarczy niewykonanie pierwotnego lotu oraz dołączenie podróżnych do listy pasażerów lotu alternatywnego na tej samej trasie ${ }^{22}$.

W razie odwołania, pasażerowie mają prawo do pomocy na zasadach określonych w art. 8 oraz 9 rozporządzenia oraz prawo uzyskania zryczałtowanego odszkodowania na zasadach określonych w art. 7, chyba że:

1) zostali poinformowani o odwołaniu lotu na co najmniej $14 \mathrm{dni}$ przed planowanym odlotem;

2) zostali poinformowani o odwołaniu lotu w okresie od 7 do 14 dni przed odlotem i zaoferowano im podróż alternatywną, umożliwiającą wylot najwcześniej 2 godziny przed planowanym czasem odlotu i dotarcie do miejsca docelowego najpóźniej 4 godziny po planowanym czasie przylotu;

3) zostali poinformowani o odwołaniu na mniej niż 7 dni przed czasem odlotu i zaoferowano im zmianę, umożliwiającą wylot, na nie więcej niż godzinę wcześniej i dotarcie do miejsca docelowego nie później, niż 2 godziny po planowanym czasie przylotu.

2.2.3 Opóźnienie lotu

Zgodnie z art. 6 rozporządzenia, jeśli przewoźnik ma powody podejrzewać, że lot będzie opóźniony o 2 lub więcej godzin (loty do 1500 km), 3 lub więcej godzin (loty wewnątrzwspólnotowe powyżej $1500 \mathrm{~km}$ oraz loty pozawspólnotowe o długości 1500-3500 km) lub 4 i więcej godzin (w przypadku wszystkich pozostałych lotów) pasażerowie powinni otrzymać pomoc zgodnie $\mathrm{z}$ art. 9 (tj. posiłki oraz możliwość kontaktu w postaci bezpłatnych rozmów telefonicznych, faksu lub wiadomości e-mail, a gdy to konieczne zakwaterowanie w hotelu oraz transport). W przypadku, gdy opóźnienie wyniesie powyżej 5 godzin pasażerowie powinni otrzymać wybór między zwrotem ceny biletu, a podróżą alternatywną na zasadach określonych $\mathrm{w}$ art. 8 rozporządzenia.

Warto zaznaczyć, że choć rozporządzenie nie przyznaje odszkodowania za opóźnienie, Trybunał Sprawiedliwości orzekł ${ }^{23}$, iż w przypadku du-

21 Wytyczne interpretacyjne..., pkt 3.1.1.

22 Wytyczne interpretacyjne..., pkt 3.2.1.

23 Sprawy połączone C-402/02 oraz C-432/07 Sturgeon i in. 
żego opóźnienia, pasażerowie doznają podobnej szkody, co w przypadku odwołania lotu. Trybunał powołał się na zasadę równego traktowania, przyznając zryczałtowane odszkodowanie także pasażerom, którzy przybyli do miejsca docelowego z co najmniej trzygodzinnym opóźnieniem ${ }^{24}$.

$\mathrm{W}$ praktyce, godzinę przylotu określa się jako moment, w którym co najmniej jedne drzwi samolotu zostają otwarte, umożliwiając pasażerom opuszczenie pokładu ${ }^{25}$

W przypadku lotów łączonych, połączonych bezpośrednio przez linie lotnicze i odbywających się w ramach jednej rezerwacji (jednej odprawy), opóźnienie liczone jest w odniesieniu do planowanej godziny przybycia do miejsca docelowego ${ }^{26}$. Co istotne, zasada ta znajduje zastosowanie jedynie w przypadku lotów połączonych przez przewoźników. W praktyce pasażerowie często samodzielnie łączą loty różnych przewoźników na poczet tej samej podróży lub też wybierają opcje łączone, oferowane przez pośredników. W takich wypadkach, opóźnienie jednego z lotów nie będzie uprawniało pasażera do uzyskania odszkodowania ani zmiany planu podróży na warunkach określonych w rozporządzeniu. Sąd Najwyższy przychylił się do tego stanowiska w wyroku I CNP 7/15 z 24 lutego 2016 r. oddalając skargę powódki w zakresie szkód, jakich doznała w wyniku odwołania lotu do USA, obsługiwanego przez polskie linie lotnicze. W wyniku odwołania, pasażerka musiała odpłatnie dokonać zmiany rezerwacji kolejnego lotu na terytorium USA, obsługiwanego przez amerykańskiego przewoźnika w ramach osobnej umowy przelotu. Sąd Najwyższy zaznaczył:

Z pewnościa jednak odszkodowanie nie może dotyczyć szkody, która nie powstała $z$ przyczyn leżących po stronie pozwanego, gdyż nie ma normalnego zwiazku przyczynowego między podróżami lotniczymi różnych przewoźników na podstawie odrębnie zawartych umów, a nie jednej umowy na przewóz kolejnymi środkami transportu. W sprawie dostrzec można tylko taki związek przyczynowy, który wyniknąt z ułożenia sobie podróży przez powódkę w określony sposób, czyli że chciała skorelować ze soba oba przeloty, ale to się w rzeczywistości jej nie udato ${ }^{27}$.

Rozporządzenie 261/2004 reguluje także przeniesienie pasażera do klasy wyższej lub niższej, niż określona w rezerwacji. Art. 10 rozporządzenia przewiduje odszkodowanie w przypadku przeniesienia do klasy niższej. Odszkodowanie wynosi 30\%, 50\% lub 75\% ceny biletu, w zależności od długości lotu. Jeśli podróż pasażera obejmowała kilka odcinków lotu, zaś

24 Wytyczne interpretacyjne..., pkt 4.4.6.

25 Ibidem, pkt 3.3.3.

26 T. Kęska-Leszyński, Rozporządzenie 261/2004 ustanawiające wspólne zasady odszkodowania i pomocy dla pasażerów w przypadku odmowy przyjęcia na pokład albo odwołania lub dużego opóźnienia lotów. Komentarz, Warszawa 2019, s. 113.

27 Wyrok Sądu Najwyższego z 24 lutego 2016 r., sygnatura I CNP 7/15. Dostępny online: https://www.saos.org.pl/judgments/244714 (dostęp: 04.08.2021). 
zmiana klasy na niższą miała miejsce jedynie podczas jednego z odcinków, rekompensata za umieszczenie w klasie niższej przysługiwać będzie jedynie za dany odcinek lotu ${ }^{28}$.

\subsubsection{0dszkodowanie}

W przypadku odwołania, opóźnienia lotu lub odmowy przyjęcia na pokład, rozporządzenie przyznaje pasażerom zryczałtowane odszkodowanie w wysokości 250 EUR, 400 EUR lub 600 EUR, w zależności od długości lotu ${ }^{29}$. Treść rozporządzenia wyraźnie wskazuje, że przy określaniu długości lotu, podstawą jest ostatni cel lotu, co jest szczególnie ważne w przypadku lotów łączonych. Obsługujący przewoźnik lotniczy ma możliwość obniżenia wysokości odszkodowania o 50\%, jeśli w wyniku zaoferowanego lotu alternatywnego pasażerowie przybędą do miejsca docelowego z opóźnieniem nie przekraczającym 2 godzin (loty do $1500 \mathrm{~km}$ ), 3 godzin (loty wewnątrzwspólnotowe powyżej $1500 \mathrm{~km}$ oraz pozostałe loty o długości 1500-3500 km) lub 4 godzin (w przypadku pozostałych lotów). Zgodnie $\mathrm{z}$ art. 7 ust. 3, odszkodowanie powinno zostać wypłacone $\mathrm{w}$ formie gotówki, elektronicznym przelewem bankowym, przekazem bankowym lub czekami bankowymi albo za pisemną zgodą pasażera w bonach podróżnych i/lub w formie innych usług. Wyraźnie widać więc, że wydanie vouchera powinno odbywać się wyłącznie za zgodą pasażera.

Konstrukcja zryczałtowanego odszkodowania pozwala pasażerom na uzyskanie rekompensaty za doznane niedogodności oraz utracony czas, bez konieczności wykazania indywidualnej szkody w postępowaniu sądowym $^{30}$.

Przewoźnik nie jest zobligowany do wypłacenia odszkodowania, jeśli odwołanie lub opóźnienie powstało wskutek nadzwyczajnych okoliczności, których nie można było uniknąć pomimo podjęcia wszelkich racjonalnych środków. Oba wspomniane warunki powinny wystąpić łącznie.

Do nadzwyczajnych okoliczności zaliczyć można m.in.:

- warunki meteorologiczne uniemożliwiające wykonanie danego lotu ${ }^{31}$;

- zagrożenie bezpieczeństwa ${ }^{32}$;

28 Wytyczne interpretacyjne..., pkt 4.4.11.

29250 EUR - w przypadku lotów o długości do 1500 km, 400 EUR - loty wewnątrzwspólnotowe o długości ponad $1500 \mathrm{~km}$ oraz pozostałe loty o długości 1500$3500 \mathrm{~km}$ oraz 600 EUR w przypadku pozaunijnych lotów o długości większej niż 3500 $\mathrm{km}$.

30 T. Kęska-Leszyński, Rozporzadzenie 261/2004..., op. cit., s. 116.

31 Rozporządzenie nr 261/2004, ustanawiające wspólne zasady odszkodowania i pomocy dla pasażerów w przypadku odmowy przyjęcia na pokład albo odwołania lub dużego opóźnienia lotów, uchylające Rozporządzenie (EWG) nr 295/911 (Rozporządzenie 261/2004) preambuła, motyw 14.

32 Ibidem. 
- nieoczekiwane wady mające wpływ na bezpieczeństwo lotu ${ }^{33}$;

- strajk o charakterze zewnętrznym wobec przewoźnika (np. strajk pracowników lotniska/kontrolerów lotu) ${ }^{34}$;

- zderzenie statku powietrznego z ptakiem ${ }^{35}$;

- decyzje kierownictwa lotów ${ }^{36}$.

Zgodnie z wytycznymi interpretacyjnymi do rozporządzenia, problemy techniczne mogą stanowić nadzwyczajne okoliczności pod warunkiem, że dana usterka nie wpisuje się w ramy normalnego wykonywania działalności lotniczej oraz, że pozostaje ona poza skuteczną kontrolą przewoźnika z uwagi na swój charakter lub źródło ${ }^{37}$. Nie stanowi nadzwyczajnej okoliczności problem techniczny, wykryty podczas obsługi technicznej statku lub z powodu braku takiej obsługi, ani też np. zderzenie ruchomych schodów z samolotem. Sytuacja wygląda jednak inaczej, jeśli źródłem usterki jest ukryta wada konstrukcyjna, ujawniona przez producenta lub gdy do usterki doszło w wyniku aktów terroryzmu.

W tym miejscu warto zauważyć, że nadzwyczajne okoliczności zwalniają przewoźnika $\mathrm{z}$ obowiązku wypłaty zryczałtowanego odszkodowania. Pozostają jednak bez wpływu na obowiązki wynikające $z$ art. 8 oraz 9 rozporządzenia.

\subsubsection{Prawo do zmiany planu podróży}

Zgodnie z art. 8 rozporządzenia, w przypadku odwołania lotu lub opóźnienia o co najmniej 5 godzin w stosunku do planowanej godziny odlotu, przewoźnik powinien dać pasażerom wybór między:

- zwrotem w terminie 7 dni środków za niewykorzystaną część podróży oraz za części już odbyte, jeśli lot nie służy już jakiemukolwiek celowi, a także, gdy jest to odpowiednie, lotem powrotnym do pierwszego miejsca odlotu w najbliższym możliwym terminie

lub

- zmianą planu podróży na porównywalnych warunkach do miejsca docelowego, w najbliższym możliwym terminie lub

33 Ibidem. Było to szczególnie istotne podczas światowego uziemienia samolotów Boeing 737-MAX.

34 Ibidem.

W tym miejscu warto zaznaczyć, że zgodnie $\mathrm{z}$ orzecznictwem TSUE strajk wewnętrzny tj. zapowiedziany legalny, mający na celu dochodzenie żądań pracowników przewoźnika nie jest objęty zakresem "nadzwyczajnych okoliczności”, znajdujących się poza kontrolą linii lotniczej (Wyrok TSUE C-28/20 z 23 marca 2021 r. w/s Airhelp vs. Scandinavian Airlines System).

35 Wyrok TSUE C-315/15 M. Pešková vs Travel Service.

36 Rozporządzenie 261/2004, preambuła, motyw 15.

37 Wytyczne interpretacyjne..., pkt 5.1. 
- zmianą planu podróży na porównywalnych warunkach do miejsca docelowego w późniejszym dogodnym terminie, w zależności od dostępności wolnych miejsc.

Jeśli dany region obsługiwany jest przez więcej niż jedno lotnisko, zgodnie $\mathrm{z}$ art. 8 ust. 3, przewoźnik może zaoferować lot na inne lotnisko niż oryginalne lotnisko rezerwacji. W takim wypadku przewoźnik powinien ponieść koszt transportu pasażera na lotnisko, na które została dokonana rezerwacja lub $\mathrm{w}$ inne miejsce uzgodnione $\mathrm{z}$ pasażerem.

Przewoźnik lotniczy powinien zaproponować pasażerom wybór między zwrotem środków, a podróżą alternatywną. Jeśli przewoźnik jednostronnie zadecyduje o dokonaniu zwrotu środków, pasażer może domagać się zwrotu różnicy ceny alternatywnego biletu ${ }^{38}$.

Co ważne, w praktyce termin „w najbliższym możliwym terminie”, oznaczać może nawet okres kilku dni (w zależności od dostępności lotów). Jeśli przewoźnik lotniczy zaproponuje lot alternatywny na porównywalnych warunkach, odbywający się w rozsądnym terminie, lecz pasażer odrzuci tę propozycję i samodzielnie dokona nowej rezerwacji, przewoźnik lotniczy nie będzie odpowiedzialny za pokrycie różnicy w cenie biletów.

2.2.6 Prawo do opieki

Pasażerom odwołanych oraz opóźnionych lotów, zgodnie z art. 9 rozporządzenia, przysługuje też tzw. prawo do opieki. Obejmuje ono uzyskanie bezpłatnych posiłków oraz napojów w ilości adekwatnej do czasu oczekiwania na opóźniony lot lub lot alternatywny, a gdy to konieczne, także zakwaterowania w hotelu oraz transportu między lotniskiem, a miejscem zakwaterowania.

Przewoźnik lotniczy powinien aktywnie oferować opiekę pasażerom, zwracając szczególną uwagę na potrzeby osób z niepełnosprawnościami oraz o ograniczonej możliwości poruszania się. Przewoźnik ma obowiązek zapewnienia posiłków oraz napojów, w ilościach adekwatnych do czasu oczekiwania $^{39}$. W praktyce często spotykanym rozwiązaniem jest zapewnienie pasażerom kanapek lub voucherów, umożliwiających zakupienie żywności na terenie lotniska. Jeśli przewoźnik nie wywiąże się z obowiązku opieki, pasażerowie mogą domagać się zwrotu poniesionych kosztów, o ile były one niezbędne, odpowiednie do czasu oczekiwania oraz rozsądne ${ }^{40}$. Istotne jest przy tym dokumentowanie wydatków. Prawo do opieki nie przewiduje rozliczenia ryczałtowego.

Prawo do opieki kończy się w momencie uzgodnienia z przewoźnikiem lotniczym zmiany planu podróży w późniejszym terminie dogodnym dla pasażera. Prawo do opieki ma zastosowanie w przypadku oczekiwania

38 Wytyczne interpretacyjne..., pkt 4.2.

39 Wytyczne interpretacyjne..., pkt 4.3.2.

40 Ibidem. 
na lot alternatywny w najbliższym możliwym terminie (art. 8 ust. 2 lit. b) lub podczas oczekiwania na lot powrotny do pierwotnego miejsca wylotu (zgodnie z art. 8 ust. 1 lit. a). W tym miejscu warto zwrócić uwagę na brzmienie art. 5 ust. 1b, który przyznaje pasażerom prawo do darmowego zakwaterowania w przypadku zmiany planu podróży, gdy racjonalnie spodziewany czas startu lotu alternatywnego ma nastąpić co najmniej 1 dzień po planowym starcie oryginalnego lotu. Oznacza to, że w przypadku, gdy pasażer otrzyma od przewoźnika wybór zgodnie z art. 8, lecz zdecyduje się na zwrot środków, a następnie samodzielnie, bez porozumienia z przewoźnikiem zarezerwuje podróż alternatywną, przewoźnik nie będzie odpowiedzialny za zapewnienie zakwaterowania. W praktyce ECK większość przewoźników lotniczych w takich wypadkach odmawia zwrotu środków za zakwaterowanie.

Rozporządzenie 261/2004 w art. 12 wyraźnie wskazuje, że pasażerowie mają prawo dochodzenia dalszego odszkodowania. W takim wypadku zryczałtowane odszkodowanie może zostać potrącone od kwoty dalszego odszkodowania. Zgodnie $\mathrm{z}$ art. 13, przepisy rozporządzenia nie ograniczają prawa przewoźnika lotniczego do dochodzenia roszczeń regresowych od osób trzecich. Art. 15 zawiera zakaz ograniczania lub wyłączania odpowiedzialności wynikającej z rozporządzenia, szczególnie na drodze klauzuli zawartej w umowie przewozu.

\subsection{Inne akty prawne}

Na uprawnienia pasażera wpływ mają także krajowe ramy prawne, zwłaszcza w zakresie terminów przedawnienia roszczeń. Terminy te nie zostały ujednolicone na terytorium UE. W przypadku Polski, zgodnie z art. 205c ust. 7 Ustawy Prawo lotnicze ${ }^{41}$, roszczenia majątkowe pasażerów wynikające z przepisów rozporządzenia 261/2004/WE oraz 2111/2005/WE przedawniają się z upływem 1 roku od dnia wykonania przewozu lub dnia, w którym przewóz miał być wykonany. Termin powyższy ma szczególne znaczenie praktyczne w przypadku polskich linii lotniczych. W przypadku przewoźnika zarejestrowanego poza granicami Polski, często mimo upływu ww. terminu możliwe jest dochodzenie roszczeń w kraju przewoźnika. Większość Państw UE przewiduje w swoich porządkach prawnych dłuższe, dwu- lub trzyletnie okresy przedawnienia.

Istotne znaczenie mają też postanowienia Ogólnych Warunków Przewozu (OWP) akceptowanych przez pasażerów podczas rezerwacji. Choć przepisy rozporządzenia 261/2004 zakazują ograniczania praw pasażera, w praktyce można niekiedy spotkać postanowienia umowne ograniczające możliwość zmiany planu podróży w innym terminie uzgodnionym z pasażerem (art. 8 ust. 1 lit. c) do ściśle określonych ram czasowych,

41 Ustawa z dnia 3 lipca 2002 r., Prawo lotnicze, Dz. U. 2002 nr 130 poz. 1112 z późn. zm. 
obejmujących zaledwie 1-2 miesiące w stosunku do oryginalnego terminu odlotu. Najczęściej przewoźnicy powołują się na fakt zaakceptowania przez pasażera OWP, w tym także warunków dokonania zmian w rezerwacji w przypadku odwołania lotu.

W przypadku lotów stanowiących część imprezy turystycznej, zastosowanie znaleźć może także ustawa z dnia 24 listopada 2017 r. o imprezach turystycznych i powiązanych usługach turystycznych (Dz. U. poz. 2361). Zgodnie z art. 48 ww. ustawy Organizator turystyki ponosi odpowiedzialność za wykonanie ustug turystycznych objętych umowa o udział w imprezie turystycznej, bez względu na to, czy usługi te maja być wykonane przez organizatora turystyki, czy przez innych dostawców usług turystycznych. Jeżeli impreza turystyczna obejmuje przewóz, organizator zobowiązany jest do zapewnienia świadczenia zastępczego, a gdy z powodu nadzwyczajnych okoliczności jest to niemożliwe, organizator podróży ponosi koszty niezbędnego zakwaterowania do 3 nocy. Wspomniana ustawa przewiduje możliwość rezygnacji z imprezy turystycznej, jeśli w miejscu docelowym lub jego najbliższym sąsiedztwie wystąpią nadzwyczajne okoliczności mające wpływ na przebieg imprezy turystycznej lub transport do miejsca docelowego. W takim wypadku, zwrot środków powinien mieć miejsce w terminie 14 dni od rozwiązania umowy.

\section{Prawa pasażera w dobie epidemii COVID-19}

Europejskie Centrum Konsumenckie w Polsce stanowi część ECC-net (European Consumer Centres Network), sieci tworzonej przez 30 centrów partnerskich, mieszczących się we wszystkich państwach członkowskich UE, Islandii, Norwegii oraz Wielkiej Brytanii ${ }^{42}$. ECK Polska jest projektem UE, realizowanym przy Prezesie Urzędu Ochrony Konkurencji i Konsumentów. ECC-net zapewnia konsumentom, zamieszkałym na terytorium działania sieci, darmowe poradnictwo oraz polubowne rozwiązywanie sporów $\mathrm{w}$ ramach nieformalnej, pozasądowej procedury. ECC-net prowadzi wyłącznie postępowania o charakterze transgranicznym. Centra sieci nie dysponują środkami przymusu wobec przedsiębiorcy, ani nie uczestniczą w postępowaniach sądowych. ECC-net, z uwagi na wyjątkową strukturę, dysponuje perspektywą, pozwalającą obserwować bieżące problemy konsumenckie w kraju oraz w Europie, w tym także problemy dotykające sektora lotniczego.

Trwająca od ponad roku epidemia COVID-19 miała znaczący wpływ na pracę ECK w Polsce oraz całej sieci ECC-net. Przede wszystkim, spowodowała lawinowy skok wpływających skarg i zapytań. W roku 2020 odnotowano $22 \%$ wzrost liczby skarg w stosunku do roku poprzedniego. W $2020 \mathrm{r}$.

$42 \mathrm{Z}$ uwagi na opuszczenie przez Wielką Brytanię Unii Europejskiej, z informacji dostępnych obecnie wynika, że ECK Wielka Brytania pozostanie częścią ECC-net jedynie do końca 2021 r. 
ECK Polska otrzymało 5969 skarg o charakterze transgranicznym oraz 1633 zapytań ${ }^{43}$. Od początku epidemii COVID-19 centrum otrzymało przeszło 3000 skarg oraz zapytań ${ }^{44}$, z czego $61 \%$ zgłoszeń dotyczyło podróży lotniczych. Na kolejnych miejscach znalazły się zgłoszenia związane z zakwaterowaniem, a także imprezy turystyczne i inne usługi transportowe.

W związku z nadzwyczajną sytuacją, wyraźnej zmianie uległa struktura skarg wpływających do ECK Polska. Miejsce najliczniejszych skarg bagażowych oraz opóźnień zajęly skargi dotyczące odwołania lotów, nieuczciwych praktyk przewoźników, czy problemów związanych z uzyskaniem zwrotów w przypadku rezerwacji przez pośrednika. Wraz z rozwojem pandemii oraz stopniowym przywracaniem ruchu lotniczego, pojawiają się także nowe problemy, niespotykane w latach poprzednich.

Doświadczenia ECC-net pokrywają się w dużej mierze z wnioskami Europejskiego Trybunału Obrachunkowego (ETO), opublikowanymi niedawno $\mathrm{w}$ formie specjalnego sprawozdania ${ }^{45}$. Sprawozdanie obejmuje wyniki kontroli przeprowadzonej przez Trybunał, w odniesieniu do pierwszego roku trwania pandemii w UE, tj. od marca 2020 r. do marca 2021 r.

Światowa Organizacja Zdrowia uznała COVID-19 za światową pandemię 11 marca 2020 r. W tym czasie państwa członkowskie wprowadziły ograniczenia w przemieszczaniu się oraz lokalne restrykcje, a znaczna część państw UE przywróciła czasowo kontrole graniczne. Trybunał Obrachunkowy zwrócił uwagę na fakt, iż restrykcje wprowadzane były jednostronnie, decyzją państw członkowskich i ogłaszane z niewielkim wyprzedzeniem $^{46}$. Wprowadzone obostrzenia oraz fakt częstego odwoływania lotów przez linie lotnicze sprawił, że podróżowanie po Europie było niezwykle utrudnione, zaś niepewność, co do potencjalnych restrykcji oraz czasowe zamknięcie szlaków powietrznych sprawiły, że europejski sektor lotniczy szczególnie ucierpiał w wyniku pandemii. Według szacunków Trybunału, w kwietniu 2020 r. odbyło się o 88\% mniej lotów, niż w tym samym okresie w 2019 r., a linie lotnicze zmuszone były anulować 50 mln biletów ${ }^{47}$. Systemy obsługi klienta linii lotniczych oraz system BSP ${ }^{48}$ nie zostały zaprojektowane w sposób pozwalający na dokonywanie masowych zwrotów pasażerom. W efekcie dało się zauważyć zastój w realizacji zwrotów. Krótki,

43 https://konsument.gov.pl/aktualnosci/2020-rok-skarg-covid-19/(dostęp:09.08.2021).

44 Według stanu na dzień 15 sierpnia $2021 \mathrm{r}$.

45 Sprawozdanie specjalne. Prawa pasażerów lotniczych $w$ czasie pandemii COVID-19 - pomimo wysiłków podejmowanych przez Komisję nie zapewniono ochrony najważniejszych praw. Europejski Trybunał Obrachunkowy, Unia Europejska 2021, https://www.eca.europa.eu/pl/Pages/DocItem.aspx?did=58696 (dostęp: 12.08.2021).

46 Ibidem, s. 12.

47 Ibidem, s. 14.

48 Ang. Billing and Settlement System - System sprzedaży biletów akredytowany przez IATA (International Air Transport Association). Więcej informacji: https://www .iata.org/en/services/finance/bsp/ (dostęp: 12.08.2021). 
Wykres 1. Epidemia COVID-19 w zgłoszeniach wpływających do ECK Polska

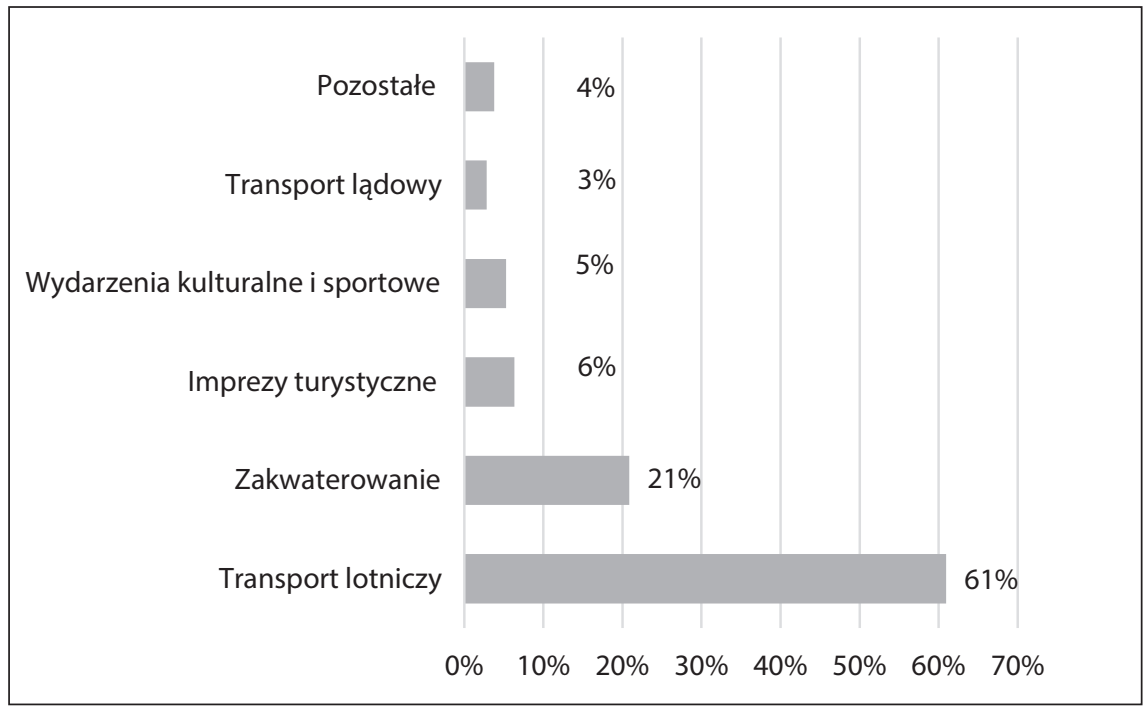

Źródło: opracowanie własne.

7-dniowy termin zwrotu środków za odwołany lot, w wielu przypadkach stał się fikcją.

Trybunał podkreśla, że światowa pandemia stanowi bezprecedensowe wydarzenie w historii lotnictwa. W Polsce od 15 marca do 15 czerwca 2020 r. wprowadzono zakaz cywilnych lotów międzynarodowych ${ }^{49}$ skutku- $^{-}$ jący odwołaniem niemal wszystkich lotów pasażerskich (wyjątek stanowiły m.in. „Loty do domu” realizowane przez PLL LOT).

Już w poprzednim sprawozdaniu ETO z 2018 roku, instytucja ta zwracała uwagę na problemy dotyczące ochrony praw pasażera. Głównym problemem pozostawał niski stan świadomości pasażerów w zakresie przysługujących praw, brak uprawnień po stronie Komisji, by zapewnić przestrzeganie przepisów, a także fakt, iż nie wszystkie organy odpowiedzialne za egzekwowanie przepisów rozporządzenia 261/2004 (National Enforcement Bodies - NEB), posiadają kompetencje w zakresie rozpatrywania spraw indywidualnych ${ }^{50}$. W chwili obecnej NEB w Niemczech, Holandii, Francji, Polsce oraz we Włoszech nie wydają decyzji w sprawach indywidualnych. W Polsce, nowelizacją ustawy Prawo lotnicze, od 1 kwietnia

49 Źródło: Strona internetowa Urzędu Lotnictwa Cywilnego : https://www.ulc.gov .pl/pl/aktualnosci/4968-zamkniecie-miedzynarodowych-polaczen-lotniczych (dostęp: 12.08.2021).

50 Sprawozdanie specjalne nr 30/2018: Prawa pasażerów w UE mają szeroki zakres, jednak pasażerowie wciąż muszą domagać się ich przestrzegania, Europejski Trybunał Obrachunkowy, Unia Europejska 2018. Dostępny online: https://www.eca .europa.eu/pl/Pages/DocItem.aspx?did=47547 (dostęp: 12.08.2021). 
2019 r., wprowadzono podmiot $\mathrm{ADR}^{51}$, zajmujący się sporami wynikającymi z rozporządzenia 261/2004. Podmiot ten zastąpił funkcjonującą wcześniej Komisję Ochrony Praw Pasażera, rozpatrującą wnioski w drodze wydania decyzji administracyjnej.

Od początku pandemii ECK Polska odnotowało znaczny wzrost zapytań, dotyczących odwołanych lotów. Do centrum wpływały zarówno skargi pasażerów, których loty zostały odwołane przez linię lotniczą, jak i zapytania pasażerów, którzy nie czekając na odwołanie lotu przez przewoźnika samodzielnie rezygnowali z podróży. Podczas, gdy w pierwszym z opisywanych przypadków bez wątpienia pasażerom przysługiwał zwrot za rezerwację, zaś ewentualne problemy pojawiały się na etapie przekazania środków przez przewoźnika, w przypadku rezerwacji odwołanych samodzielnie przez pasażerów, zastosowanie znajdują ogólne warunki przewozu. Złożenie przez pasażera oświadczenia o anulowaniu rezerwacji najczęściej wiązało się więc z naliczeniem opłaty, a w przypadku rezerwacji bezzwrotnych - z utratą wpłaconej kwoty. W większości przypadków fakt późniejszego odwołania lotu przez przewoźnika pozostawał bez znaczenia dla sytuacji pasażerów. Linie lotnicze utrzymywały, że pasażer zaakceptował warunki taryfy podczas dokonywania rezerwacji, a następnie złożył wiążące oświadczenie woli w zakresie anulowania rezygnacji zgodnie z OWP. Doświadczenie ECK wskazuje, że w wyżej opisanych przypadkach nie było możliwe osiągnięcie polubownego rozwiązania sporu. Ewentualne dalsze roszczenia mogłyby być procedowane na drodze sądowej.

Wraz z rozwojem pandemii wzrosła także liczba osób, próbujących bezpłatnie odwołać rezerwację lotniczą z uwagi na własne obawy lub obostrzenia (np. konieczność szczepienia/testu) w miejscu docelowym. W większości przypadków okoliczności te nie uprawiają pasażerów do otrzymania zwrotu, zwłaszcza jeśli rezerwacji dokonano już w trakcie pandemii.

Problemem, który wyraźnie zarysował się na początku epidemii, była przyjęta przez część przewoźników (oraz dopuszczona przez Włochy oraz Grecję) praktyka dokonywania zwrotów w formie vouchera. Praktyka ta była szczególnie dotkliwa, w przypadku gdy vouchery wydawano pasażerom automatycznie, przy jednoczesnym uniemożliwieniu złożenia wniosku o zwrot w formie pieniężnej ${ }^{52}$. W praktyce dało się także zaobserwować automatyczne wystawianie voucherów, mimo składanych przez pasażera wniosków o zwrot środków. Skutkowało to koniecznością każdorazowego odrzucania przez pasażera vouchera lub złożenia osobnego wniosku o zwrot.

Znaczące zmiany w stosowanych praktykach linii lotniczych można przypisać działaniom Komisji Europejskiej tj. wydanemu w maju 2020 r.

51 Rzecznik Praw Pasażera Lotniczego. Rzecznik prowadzi postępowania polubowne (mediacje) w sprawach objętych zakresem rozporządzenia 261/2004. Więcej informacji: https://pasazerlotniczy.ulc.gov.pl/(dostęp: 12.08.2021).

52 Sprawozdanie specjalne. Prawa pasażerów lotniczych..., s. 26. 
stanowisku, w którym wskazano, że odstępstwa od przepisów rozporządzenia 261/2004 są niedopuszczalne oraz wszczętym w lipcu 2020 r. postępowaniom wobec państw członkowskich, których działania uchybiły zobowiązaniom traktatowym ${ }^{53}$.

Problem voucherów nie dotyczył jedynie przewoźników. Znaczna część pośredników rezerwacji także znalazła się $\mathrm{w}$ trudnej sytuacji finansowej. Część z nich próbowała postawić klientów przed faktem dokonanym, proponując jedynie zwrot $\mathrm{w}$ formie voucherów lub też dezaktywując inne metody kontaktu (takie jak infolinie, adresy e-mail czy formularze). Niektórzy pośrednicy próbowali przekonać klientów do wyboru voucherów oferując jedynie 2 opcje: voucher lub samodzielne dochodzenie przez pasażera zwrotu od linii lotniczej. Było to niezwykle trudne w przypadku, gdy pasażer nie posiadał danych użytych przez pośrednika do dokonania rezerwacji. Powstawało niejako „błędne koło reklamacji”, w którym linia lotnicza odsyłała pasażerów do pośrednika, zaś pośrednik - do linii lotniczej. Pośrednicy argumentowali przy tym, że na podstawie rozporządzenia, to obsługujący przewoźnik odpowiedzialny jest za zwrot środków. Linie lotnicze z kolei odsyłały do pośredników wskazując, że zwrot środków powinien odbywać się $\mathrm{w}$ tej samej formie, co oryginalna płatność. W związku z powyższym, aby otrzymać zwrot za rezerwację, pasażerowie wielokrotnie musieli kontaktować się zarówno z jednym, jak i z drugim podmiotem. W przypadku lotów łączonych ECK napotkało też na problemy wynikające ze wzajemnego odsyłania pasażera nie tylko między pośrednikiem a przewoźnikiem, lecz także między przewoźnikiem faktycznym oraz przewoźnikiem umownym (wystawcą biletu). W stosunku do niektórych pośredników odnotowano brak możliwości kontaktu lub bardzo ograniczony kontakt w sprawie istniejących rezerwacji.

Oprócz problemów wynikających z realizacji zwrotów, zaobserwowano naliczanie po stronie niektórych pośredników odrębnych opłat za wtórną obsługę rezerwacji (tj. zgłoszenie roszczenia do linii lotniczej), wynoszących od ok. 20 do 40 EUR za rezerwację. Choć status tych opłat nie wzbudza większych wątpliwości, w przypadku rezerwacji dokonywanych już w trakcie trwania pandemii (tj. po wprowadzeniu ww. opłat do regulaminów), do centrum docierały także głosy wskazujące na brak informacji o ww. opłatach w umowach akceptowanych w momencie dokonywania rezerwacji. Niestety, żadne z otrzymanych zgłoszeń nie zawierało dowodów potwierdzających twierdzenia konsumenta, co uniemożliwiło podjęcie postępowania w sprawie.

Przepisy, w oparciu o które działają pośrednicy zależą od państwa członkowskiego rejestracji. Obecna sytuacja niewątpliwie obnażyła problemy, wynikające $\mathrm{z}$ braku regulacji działania pośredników na poziomie UE.

53 Ibidem, s. 27. 
W ostatnim czasie ujawniają się problemy wynikające ze znacznego upływu czasu od momentu rezerwacji. Część przedsiębiorców wskazuje, że w sytuacji, gdy płatności dokonano ponad rok temu, automatyczny zwrot w systemie rezerwacji nie jest możliwy. Oznacza to, że każdy zwrot musi zostać przetworzony ręcznie, co wydłuża czas oczekiwania na środki. Zaobserwowano również problemy wynikające z utraty ważności karty użytej do dokonania rezerwacji lub zamknięcia oryginalnego konta bankowego przez pasażera. Stosowane systemy rezerwacji zostały opracowane z myślą o dużo mniejszej skali dokonywanych zwrotów oraz zwrotów dokonywanych w krótszym czasie. Systemy te są obecnie wysoce zautomatyzowane, przez co zwrot środków zaakceptowany przez przewoźnika jest automatycznie procedowany zgodnie $\mathrm{z}$ oryginalną formą płatności. W ostatnim czasie do ECK trafiają skargi, w których konsumenci podnoszą, iż nie otrzymali zwrotu środków, chociaż linia lotnicza przedstawiła dowód dokonania przelewu. Niekiedy zdarza się, że przelew zostanie zdeponowany na bankowym koncie tymczasowym lub też zwrócony do nadawcy, lecz nie zostaje zaksięgowany przez system przewoźnika. W sprawach tego rodzaju przydatne jest uzyskanie zaświadczenia z odpowiedniego banku. Niestety, może się to wiązać $\mathrm{z}$ dodatkowymi kosztami dla pasażera.

Nową kategorię spraw wpływających do ECK Polska stanowią zgłoszenia dotyczące niewpuszczenia pasażerów na pokład z uwagi na wprowadzone przez państwa członkowskie restrykcje (np. brak testu PCR lub brak certyfikatu szczepienia). Tę rosnącą kategorię spraw można podzielić na:

1) Sytuację, w której linia lotnicza niesłusznie odmawia wejścia na pokład w wyniku błędnej analizy przepisów;

2) Sytuację, w której pasażer zaniedbał obowiązek sprawdzenia wymagań w miejscu docelowym/państwie tranzytowym.

Częstym przypadkiem wśród zgłaszanych spraw, jest pierwsza z opisanych sytuacji, tzn. błędna interpretacja przepisów państwa docelowego. Zdarza się to zwłaszcza wówczas, gdy pasażerowie podróżują tranzytem lub, gdy obowiązek posiadania testu nie dotyczy obywateli państwa docelowego (np. obywatele Ukrainy wracający do Lwowa samolotem z Polski). Jeśli dojdzie do takiej sytuacji, niezwykle istotne jest dokumentowanie poniesionych kosztów. Z doświadczenia ECK wynika, że w sprawach tego rodzaju linie lotnicze niekiedy przyznają się do błędu, jednak odmawiają wypłaty zryczałtowanego odszkodowania $\mathrm{z}$ uwagi na nadzwyczajne okoliczności (COVID-19). Z uwagi na fakt, że uprawnienia $\mathrm{z}$ art. 8 oraz 9 rozporządzenia nie przewidują ryczałtowego rozliczenia kosztów, dla późniejszego dochodzenia zwrotu środków od przewoźnika, niezbędne jest udokumentowanie wydatków poniesionych w związku z podróżą alternatywną, czy też wyżywieniem oraz zakwaterowaniem w oczekiwaniu na lot alternatywny.

Wśród zgłoszeń pasażerskich pojawiają się także sprawy związane $\mathrm{z}$ niewpuszczeniem na pokład $\mathrm{w}$ sytuacji, gdy pasażer nie wiedział 
o konieczności posiadania testów/certyfikatu COVID-19 lub rejestracji w systemie państwa docelowego. Choć każda sprawa oceniana jest indywidualnie można wskazać, że w większości przypadków linie lotnicze podtrzymują stanowisko dotyczące odmowy wejścia na pokład argumentując, że zgodnie z OWP przewoźnika, to pasażer odpowiedzialny jest za posiadanie wszelkich dokumentów koniecznych do przekroczenia przez niego granicy (np. paszportu, wizy, czy innych dokumentów wymaganych w miejscu docelowym). Dlatego też istotne jest, by przed wylotem za granicę sprawdzić obowiązujące obostrzenia, w tym także obostrzenia występujące w państwie tranzytowym. Aktualne obostrzenia występujące w danym państwie członkowskim można sprawdzić na stronie gov.pl, w zakładce Informacje dla podróżujących ${ }^{54}$, w aplikacji Polak za granica lub na europejskiej stronie Re-open.eu ${ }^{55}$.

Dokumentem ułatwiającym podróżowanie po Europie od 1 lipca $2021 \mathrm{r}$. jest także unijny certyfikat COVID-1956. Choć certyfikat stanowi duży krok $\mathrm{w}$ stronę ułatwienia przemieszczania się na terytorium UE, przed wyjazdem warto upewnić się czy będzie wystarczający. Niektóre państwa uznają certyfikaty w odniesieniu do osób zaszczepionych, lecz nie w stosunku do ozdrowieńców. Inne państwa wprowadziły ograniczenia: np. uznają, że certyfikat zwalnia z obowiązku posiadania testów jedynie w przypadku, gdy od szczepienia minęła określona, minimalna ilość dni (np. 14 dni), lecz nie minęła pewna wartość maksymalna (np. 9-10 miesięcy od zaszczepienia). W przypadku obywateli Polski, certyfikat jest dostępny także w formie cyfrowej, np. w mobilnej aplikacji mObywatel. Warto jednak posiadać ze sobą papierową wersję certyfikatu na wypadek, gdyby np.w urządzeniu mobilnym rozładowała się bateria. Jest to szczególnie istotne w państwach, które uzależniły możliwość korzystania z pewnych usług (np. muzeów, restauracji, teatrów) od przedstawienia ważnego certyfikatu szczepienia/testu na obecność COVID-19.

Wśród niebezpieczeństw czyhających na pasażerów w dobie pandemii wirusa SARS-CoV-2, odnotować należy także upadłość przewoźnika. $\mathrm{Z}$ uwagi na rozmiary obecnego kryzysu, wiele linii lotniczych znalazło się na krawędzi bankructwa. Wiele z nich uzyskało wsparcie od państwa ${ }^{57}$, jednak w stosunku do niektórych, nawet dodatkowe wsparcie nie ocaliło przewoźnika od bankructwa. Postępowania upadłościowe tych spółek toczą się według przepisów prawa krajowego miejsca siedziby przedsiębiorcy. Choć

54 https://www.gov.pl/web/dyplomacja/informacje-dla-podrozujacych/ (dostęp: 15.08.2021).

55 https://reopen.europa.eu/pl (dostęp: 15.08.2021).

56 Więcej informacji o certyfikacie: https://www.gov.pl/web/certyfikat/o -certyfikacie-informacje (dostęp: 15.08.2021).

57 Według szacunków ETO 31.8 mld EUR czyli ponad 90\% państwowej pomocy udzielonej w związku z pandemią trafiło do przewoźników lotniczych. Źródło: Sprawozdanie specjalne. Prawa pasażerów lotniczych..., op. cit., s. 40. 
terminy zgłaszania roszczeń w postępowaniu upadłościowym są ogłaszane publicznie, często zdarza się, że informacje te docierają do pokrzywdzonych konsumentów ze znacznym opóźnieniem, tym samym utrudniając dochodzenie zwrotu. W chwili obecnej coraz częściej możliwe jest wykupienie odszkodowania obejmującego swoim zakresem także ewentualną upadłość przewoźnika. Wiąże się to jednak z poniesieniem dodatkowych kosztów przez pasażera.

W zakresie odwołanych lotów oraz coraz częściej występujących przypadków wielokrotnych zmian planu podróży przez przewoźnika, nie sposób nie wspomnieć o zryczałtowanych odszkodowaniach przewidzianych przepisami rozporządzenia 261/2004. Mimo iż pandemia trwa od ponad roku, przybywa zgłoszeń, w których przewoźnicy odmówili wypłaty odszkodowania powołując się na COVID-19, nawet wtedy, gdy przyczyną odwołania lotu były np. względy techniczne. Możliwość weryfikacji twierdzeń przewoźnika posiadają niektóre z organów wyznaczonych do egzekwowania przepisów Rozporządzenia (NEB) oraz sądy.

\section{Dochodzenie roszczeń}

System ochrony praw pasażera w Polsce jest dość złożony instytucjonalnie. Najmniej wątpliwości budzi zakres kompetencji Rzecznika Praw Pasażera Lotniczego. Rzecznik może przyjąć skargę w przypadku zdarzeń objętych przepisami rozporządzenia 261/2004 w przypadku gdy:

1) Lot odbywa się z terytorium Polski - niezależnie od siedziby przewoźnika;

2) Lot rozpoczyna się w państwie trzecim, lecz kończy na terytorium Polski - o ile przewoźnikiem jest przewoźnik wspólnotowy.

Rzecznik Praw Pasażera prowadzi postępowania w sporach pasażerskich. Warto podkreślić, że choć instytucje konsumenckie także zajmują się postępowaniami z zakresu praw pasażera, pojęcia: „pasażer” oraz „konsument" - nie są tożsame.

Zakres działalności ECC-net częściowo pokrywa się z właściwością Rzecznika. ECK Polska przyjmuje skargi transgraniczne, tzn. wynikające z umów zawartych między konsumentami zamieszkałymi na terytorium Polski a przedsiębiorcami zarejestrowanymi na terytorium jednego z pozostałych Państw UE, Islandii, Norwegii lub Wielkiej Brytanii. O właściwości ECK Polska decyduje więc konsumencki charakter sprawy (tj. niezwiązany bezpośrednio z działalnością gospodarczą lub zawodową pasażera); oraz miejsce zamieszkania konsumenta.

Właściwość ECK nie jest określana przy pomocy obywatelstwa. Tak więc Polak mieszkający w Niemczech powinien zgłosić swoją skargę do ECK Niemcy, zaś konsument narodowości czeskiej mieszkający w Polsce do ECK Polska jako centrum miejsca zamieszkania. 
Konsumenci, których loty znajdują się we właściwości obu instytucji, mogą wybrać preferowaną ścieżkę polubownego dochodzenia roszczeń. Warto mieć jednak na uwadze, że w przeciwieństwie do Rzecznika Praw Pasażera wniesienie skargi do ECK Polska nie skutkuje wstrzymaniem biegu przedawnienia roszczeń. Z kolei w przypadku ECK występuje szerszy katalog roszczeń, obejmujący uprawnienia wynikające z Konwencji Montrealskiej (zagubiony lub uszkodzony bagaż) oraz bazujące na innych przepisach prawa (np. problemy związane z płatnością, zmianami w rezerwacji dokonywanymi przez pasażera). Naturalnie, dotyczy to jedynie skarg przeciwko podmiotom zagranicznym.

W przypadku spraw bagażowo-rezerwacyjnych, prowadzonych przeciwko przewoźnikom krajowym, wydaje się, że właściwe pozostają krajowe instytucje konsumenckie tj. Rzecznicy Konsumentów, organizacje konsumenckie oraz Wojewódzkie Inspektoraty Inspekcji Handlowej (WIIH).

W przypadku Rzeczników Konsumentów ${ }^{58}$, właściwość określa miejsce zamieszkania konsumenta. W przypadku WIIH, stanowiącego horyzontalny organ ADR, możliwe jest zgłoszenie wniosku w stosunku do podmiotów zarejestrowanych na terytorium działania danego Inspektoratu. Dla przykładu: mieszkaniec powiatu pszczyńskiego, którego bagaż uszkodzono podczas lotu Katowice-Burgas, realizowanego przez polskie linie czarterowe $\mathrm{z}$ siedzibą $\mathrm{w}$ Warszawie, mógłby dochodzić swoich roszczeń poprzez Powiatowego Rzecznika Konsumentów w Pszczynie lub składając wniosek o mediację do Wojewódzkiego Inspektoratu Inspekcji Handlowej w Warszawie. Rzecznik Praw Pasażerów przy Prezesie Urzędu Lotnictwa Cywilnego nie byłby właściwy z uwagi na charakter sporu.

Oczywiście, pasażerowie mogą dochodzić swoich roszczeń także na drodze postępowania sądowego. Niekiedy jest to jedyna dostępna ścieżka procedowania sporu. $Z$ doświadczeń ECK wynika, że mimo istnienia uproszczonej Europejskiej Procedury Drobnych Roszczeń, transgraniczne postępowania sądowe nie cieszą się popularnością wśród polskich konsumentów. Podstawowym problemem, jaki wskazują konsumenci, są trudności związane ze znalezieniem prawników specjalizujących się w postępowaniach transgranicznych, brak wiedzy/informacji nt. transgranicznego dochodzenia roszczeń oraz koszty tłumaczenia dokumentów na język sądu, w którym prowadzone ma być postępowanie.

58 Więcej informacji o Rzecznikach oraz wyszukiwarkę instytucji konsumenckich znaleźć można pod adresem: https://www.uokik.gov.pl/rzecznicy.php (dostęp: 15.08.2021). 
Tabela 2. Organy właściwe dla dochodzenia roszczeń pasażerskich w Polsce

\begin{tabular}{|c|c|c|c|}
\hline & $\begin{array}{l}\text { Przewoźnik } \\
\text { zarejestrowany } \\
\text { w Polsce }\end{array}$ & $\begin{array}{c}\text { Przewoźnik } \\
\text { zarejestrowany } \\
\text { w UE, Islandii lub } \\
\text { Norwegii }\end{array}$ & $\begin{array}{c}\text { Przewoźnik } \\
\text { zarejestrowany } \\
\text { w Państwie trzecim }\end{array}$ \\
\hline Bagaż & $\begin{array}{l}\text { Krajowe instytucje } \\
\text { konsumenckie }^{\star}\end{array}$ & ECC-net* & - \\
\hline $\begin{array}{l}\text { Odwołany lot/ } \\
\text { Opóźniony lot/ } \\
\text { Odmowa } \\
\text { przyjęcia na } \\
\text { pokład }\end{array}$ & $\begin{array}{l}\text { Rzecznik Praw } \\
\text { Pasażerów przy } \\
\text { Prezesie Urzędu } \\
\text { Lotnictwa Cywilnego } \\
\text { (wylot z terytorium } \\
\text { Polski) lub organ } \\
\text { wyznaczony } \\
\text { (NEB) w kraju } \\
\text { wylotu/przylotu } \\
\text { (w przypadku lotów } \\
\text { spoza UE) }\end{array}$ & $\begin{array}{l}\text { Rzecznik Praw } \\
\text { Pasażerów przy } \\
\text { Prezesie Urzędu } \\
\text { Lotnictwa Cywilnego } \\
\text { (wylot z terytorium } \\
\text { Polski) lub organ } \\
\text { wyznaczony } \\
\text { (NEB) w kraju } \\
\text { wylotu/przylotu } \\
\text { (w przypadku lotów } \\
\text { spoza UE); } \\
\text { ECC-net }\end{array}$ & $\begin{array}{l}\text { Rzecznik Praw } \\
\text { Pasażerów przy } \\
\text { Prezesie Urzędu } \\
\text { Lotnictwa Cywilnego } \\
\text { (wylot z terytorium } \\
\text { Polski) lub organ } \\
\text { wyznaczony (NEB) } \\
\text { w kraju wylotu. } \\
\text { Lot spoza UE - } \\
\text { brak zastosowania } \\
\text { rozporządzenia }\end{array}$ \\
\hline $\begin{array}{l}\text { Problemy } \\
\text { z rezerwacją/ } \\
\text { płatnościami }\end{array}$ & $\begin{array}{l}\text { Krajowe instytucje } \\
\text { konsumenckie }^{*}\end{array}$ & ECC-net* & - \\
\hline
\end{tabular}

\section{Podsumowanie}

Prawa pasażera lotniczego należą do kategorii uprawnień dość szczegółowo uregulowanych na gruncie prawa międzynarodowego oraz europejskiego. Mimo to, świadomość praw pasażera kształtuje się na stosunkowo niskim poziomie. Trwająca od marca 2020 r. światowa epidemia COVID-19 stanowi zdarzenie bez precedensu w historii lotnictwa. Pandemia mocno uderzyła w sektor lotniczy, obnażając nowe aspekty w zakresie ochrony praw pasażera. Przede wszystkim pandemia wykazała, że obecnie stosowane systemy rezerwacji nie są w stanie zapewnić efektywności zwrotów w przypadku anulowania większości rezerwacji. Co więcej, obecna sytuacja wyraźnie obnażyła dotkliwy brak regulacji działalności pośredników lotniczych. Działania pośredników oraz przewoźników, wzajemnie przerzucających się odpowiedzialnością za dokonanie zwrotu środków sprawiły, że w części przypadków czas procedowania zwrotów uległ wydłużeniu. Pandemia przyniosła spadek liczby lotów, a co za tym idzie mniejszą liczbę pewnych kategorii skarg (np. skargi bagażowe), lecz wykreowała nowe problemy wcześniej niespotykane w praktyce. Mimo dość szczegółowej regulacji w zakresie praw pasażera, nadal występuje wiele wątpliwości praktycznych. Każda sprawa musi więc być oceniana indywidualnie. W Polsce oraz 
Europie istnieje rozbudowany system polubownego rozwiązywania sporów $\mathrm{z}$ tytułu praw pasażera. W przypadkach szczególnie trudnych lub $\mathrm{w}$ razie niepowodzenia postępowań polubownych, wątpliwości może rozstrzygnąć sąd.

\section{Bibliografia}

Kęska-Leszyński T., Rozporządzenie 261/2004 ustanawiające wspólne zasady odszkodowania i pomocy dla pasażerów w przypadku odmowy przyjęcia na pokład albo odwołania lub dużego opóźnienia lotów. Komentarz, Warszawa 2019.

Konert A., Odpowiedzialność cywilna przewoźnika lotniczego, Warszawa 2010.

Kunert-Diallo A., Kolizje praw w międzynarodowym transporcie lotniczym, Warszawa 2011.

Polkowska M., Szymajda I., Konwencja montrealska. Komentarz. Odpowiedzialność cywilna przewoźnika lotniczego, Wydawnictwo Liber, Warszawa 2004.

Sprawozdanie specjalne: Prawa pasażerów lotniczych $w$ czasie pandemii COVID-19 - pomimo wysilków podejmowanych przez Komisje nie zapewniono ochrony najważniejszych praw, Europejski Trybunał Obrachunkowy, Unia Europejska 2021, https://www.eca.europa.eu/pl/Pages/DocItem.aspx?did=58696.

Zawiadomienie Komisji Wytyczne interpretacyjne dotyczące rozporządzenia WE nr 261/2004 Parlamentu Europejskiego i Rady ustanawiającego wspólne zasady odszkodowania i pomocy dla pasażerów w przypadku odmowy przyjęcia na pokład albo odwołania lub dużego opóźnienia lotów oraz rozporządzenia Rady (WE) nr 2027/97 w sprawie odpowiedzialności przewoźnika lotniczego $\mathrm{z}$ tytułu wypadków lotniczych zmienionego rozporządzeniem (WE) nr 889/2002 Parlamentu Europejskiego i Rady. Dziennik Urzędowy Unii Europejskiej C 214/5, https://eur-lex.europa.eu/legal-content/ $\mathrm{PL} / \mathrm{TXT} /$ ?uri=CELEX\%3A52016XC0615\%2801\%29

\section{Źródła internetowe}

EUR-LEX Baza aktów prawnych UE, https://eur-lex.europa.eu/ (dostęp: 12.07.2021).

Internetowy System aktów prawnych, https://isap.sejm.gov.pl/ (dostęp 11.07.2021).

Ministerstwo Spraw Zagranicznych. Informacje dla podróżujących, https://www .gov.pl/web/dyplomacja/informacje-dla-podrozujacych/ (dostęp: 11.07.2021).

Oficjalna strona internetowa Trybunału Sprawiedliwości Unii Europejskiej, https:// curia.europa.eu/jcms/jcms/j_6/pl/ (dostęp: 15.08.2021).

Oficjalna strona internetowa Europejskiego Trybunału Obrachunkowego, https:// www.eca.europa.eu/pl/Pages/DocItem.aspx?did=58696 (dostęp: 12.08.2021).

Oficjalna strona internetowa Międzynarodowego Stowarzyszenia Przewoźników Powietrznych (IATA), https://www.iata.org/en/services/finance/bsp/ (dostęp: 12.08.2021).

Oficjalna strona internetowa Organizacji Międzynarodowego Lotnictwa Cywilnego (ICAO), https://www.icao.int (dostęp: 11.07.2021).

Oficjalna strona internetowa Europejskiego Centrum Konsumenckiego w Polsce, https://konsument.gov.pl (dostęp: 9.08.2021). 
Oficjalna strona internetowa Urzędu Lotnictwa Cywilnego, https://www.ulc.gov .pl/pl/aktualnosci/4968-zamkniecie-miedzynarodowych-polaczen-lotniczych (dostęp: 12.08.2021).

System analizy orzeczeń sądowych. Wyrok Sądu Najwyższego z 24 lutego 2016, sygnatura I CNP 7/15. Dostępny online, https://www.saos.org.pl/judgments/244714 (dostęp: 04.08.2021).

\section{Prawa pasażera lotniczego w Europie w dobie COVID-19}

\section{Streszczenie}

Ograniczenia wprowadzone w związku z pandemią COVID-19, szczególnie uderzyły w sektor transportowy oraz turystyczny. Nietypowa sytuacja pandemiczna ujawniła mankamenty obecnych regulacji oraz konieczność dalszej harmonizacji przepisów prawa na poziomie Unii Europejskiej. Europejska sieć ECC-net stanowi ważny element ułatwiający mieszkańcom Unii Europejskiej, Islandii oraz Norwegii polubowne dochodzenie roszczeń konsumenckich, wynikających z zawartej umowy przewozu lotniczego. W przedmiotowym opracowaniu autorka skupia się na przedstawieniu obecnych ram prawnych regulujących prawa pasażera, problemach jakie ujawniła pandemia COVID-19 oraz obecnym systemie dochodzenia roszczeń pasażerskich w Polsce w ujęciu instytucjonalnym.

Słowa kluczowe: prawa pasażera lotniczego, COVID-19, polubowne dochodzenie roszczeń, prawa konsumenta, Unia Europejska

\section{Airpassenger Rights in Europe in the Times of COVID-19}

\section{Abstract}

Restrictions introduced due to the pandemic heavily affected transportation and tourism market. The unusual pandemic situation revealed certain shortcomings of the existing legal framework and the necessity of further harmonization of regulations at the European Union level. The European Consumer Centres Network (ECC-net) is an important element in air passenger rights sector in the European Union, Iceland, Norway and United Kingdom, providing help with amicable dispute resolution in consumer cases. In the article author focuses on the presentation of the current legal framework in the air passenger rights sector, as well as the problems revealed by the COVID-19 pandemic, and the institutional framework in Poland enabling passengers to pursue air passenger right.

Keywords: air passenger rights, COVID-19 pandemic, amicable investigation, consumer rights, European Union 